\title{
Effect of Larval Topical Application of Juvenile Hormone on Caste Determination in the Independent-Founding Eusocial Wasp Mischocyttarus consimilis (Hymenoptera: Vespidae)
}

\author{
Thiago S. Montagna ${ }^{1 *}$, Josué Raizer², William F. Antonialli-Junior1,3 \\ ${ }^{1}$ Programa de Pós-graduação em Entomologia e Conservação da Biodiversidade, Universidade Federal da \\ Grande Dourados, Dourados, Brazil \\ ${ }^{2}$ Faculdade de Ciências Biológicas e Ambientais, Universidade Federal da Grande Dourados, Dourados, Brazil \\ ${ }^{3}$ Laboratório de Ecologia Comportamental, Universidade Estadual de Mato Grosso do Sul, Dourados, Brazil \\ Email: "thiagomontag@yahoo.com.br
}

Received 12 February 2015; accepted 3 April 2015; published 7 April 2015

Copyright (C) 2015 by authors and Scientific Research Publishing Inc.

This work is licensed under the Creative Commons Attribution International License (CC BY).

http://creativecommons.org/licenses/by/4.0/

(c) $\underset{\mathrm{EY}}{0}$ Open Access

\begin{abstract}
Eusocial wasps are excellent models for understanding polyethism and division of labor among castes in social insects. However, little is known about the mechanisms controlling caste determination in eusocial wasps. Evidence suggests that the phenotype of queens in independent-founding (IF) eusocial wasps of the subfamily Polistinae can be partly fixed in the larval stage; however, this hypothesis has not yet been investigated. In this study we evaluate whether juvenile hormone (JH) affects pre-imaginal caste determination in the IF eusocial wasp Mischocyttarus consimilis (Hymenoptera: Vespidae). Analyzing morphometric and behavioral data, we demonstrated experimentally that females emerging from larvae that were treated with $\mathrm{JH}$ in the third instar had a significantly larger body size, spent more time in the nest, and were subject to less physical aggression from nestmates compared with females emerging from untreated control larvae. These results indicate that phenotype differences among castes in IF eusocial wasps can be partly fixed in the pre-adult stage and influenced by variations in the $\mathrm{JH}$ titer.
\end{abstract}

\section{Keywords}

Division of Labor, Reproductive Strategy, Independent-Founding, Social Insects, Polistinae

\footnotetext{
${ }^{*}$ Corresponding author.
}

How to cite this paper: Montagna, T.S., Raizer, J. and Antonialli-Junior, W.F. (2015) Effect of Larval Topical Application of Juvenile Hormone on Caste Determination in the Independent-Founding Eusocial Wasp Mischocyttarus consimilis (Hymenoptera: Vespidae). Open Journal of Animal Sciences, 5, 174-184. http://dx.doi.org/10.4236/ojas.2015.52020 


\section{Introduction}

Eusocial insects show a clear division of tasks among castes, and the reproductive function is performed by a specialized female, the queen [1]. However, in less complex societies such as independent-founding (IF) eusocial wasps, females that are subordinate to the queen retain their reproductive potential and can assume the colony reproductive function, if an opportunity arises [2] [3]. The reproductive organization of these societies is closely associated with the position of each female within a dominance hierarchy [4]. High-ranking females forage less, have greater access to food brought by foragers, and are the most likely to assume the colony reproductive function in the absence of the queen [5] [6].

In most species of eusocial insects, phenotypic differences established during pre-imaginal caste determination are the basis for the reproductive division of labor between queens and workers [7]. The apparent absence of allometric growth among castes in IF eusocial wasps has been cited as evidence against pre-imaginal caste determination [8], although evidence of pre-imaginal caste determination, including differences in body size between workers and gynes, has been presented for several species of IF eusocial wasps in the subfamily Polistinae [9]-[11]. In addition, recent studies with members of Polistes have found qualitative morphological differences among these castes, especially morphometric variation in the Van der Vecht organ secretory area [12] [13].

Phenotypic divergences among castes of eusocial insects are generated by the differential expression of genes in individuals sharing the same genotype [14]-[16]. Differential expression of genes is controlled by physiological processes that involve changes in hormone titers, and the juvenile hormone $(\mathrm{JH})$ plays an important role in this process [17] [18]. For example, in the honeybee Apis mellifera, the JH controls the differential expression of genes during the critical period of larval development, when sensitivity to this hormone increases [19] [20].

Developmental biologists speculate that $\mathrm{JH}$ can play an important role in larval developmental reprogramming in IF eusocial wasps [21] [22]. For example, it is suggested that morphological variations between workers and gynes in Polistes dominula, as well as differences in facial patterns indicating reproductive quality among these castes, are affected by variations in JH titers during larval development [21]. Similarly, quantitative differences in cuticular compounds between workers and foundresses in $P$. dominula were attributed to larval variations in $\mathrm{JH}$ titers, and this may be involved in differential gene expression linked to the behavioral phenotype of adult females in Polistes canadensis [14] [23].

The colony cycle of IF eusocial wasps is annual, and the production of castes is closely associated with the colony stage [9] [24] [25]. In these societies, workers are usually produced in the early post-emergence phase, when the colonies require a large workforce [10] [26]. Workers engage mainly in the care of immatures, foraging for resources, and colony defense [27]. In contrast, gynes are most commonly produced in late post-emergence, when colonies have large numbers of adults [24] [25]. Gynes invest in their own reproduction and contribute little to the maternal colony [28]. These data suggest that the production of workers and gynes in colonies of IF eusocial wasps is associated with the colony stage, and must involve ontogenetic differences among these castes.

Mischocyttarus consimilis (Hymenoptera: Vespidae) is an IF eusocial wasp, with colonies having a life cycle of approximately eight months [25]. The first studies of its life history were conducted only recently [25] [29][31]. Based on evidence that phenotypic differences among castes in IF eusocial wasps may be partly fixed in the immature stage, the objective of this study is to evaluate whether $\mathrm{JH}$ affects pre-imaginal caste determination in M. consimilis.

\section{Materials and Methods}

\subsection{Collection and Transfer of Colonies to Artificial Shelters}

From September 2010 to February 2013, we transferred eight colonies of $M$. consimilis from the field to artificial shelters (AS), in order to maintain, monitor and manipulate them under experimental conditions. These colonies were located in rural areas in the municipality of Dourados, state of Mato Grosso do Sul, especially in the eaves of vacant houses. Colonies were transferred to the AS in the early evening, when foraging activity had ceased and apparently all adults were present in the nest. Our study does not require an ethics statement and did not involve endangered or protected species of the Brazilian fauna.

Two AS were installed near the Laboratory of Ecology, campus of the State University of Mato Grosso do Sul, in Dourados. Each AS was built of wood $(1.2 \times 1.2 \times 2.5 \mathrm{~m})$, covered with thermal-regulating tiles and without side walls, to allow foragers to move freely to and from the field (Figure 1(a)). Each colony of M. consimilis was attached with wood glue to a wooden board $(30 \times 60 \mathrm{~cm})$ installed in each AS (Figure 1(b)). Each board 


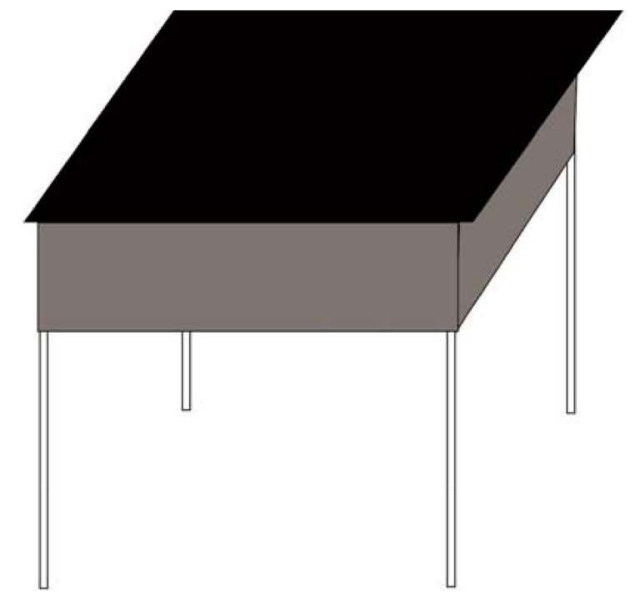

(a)

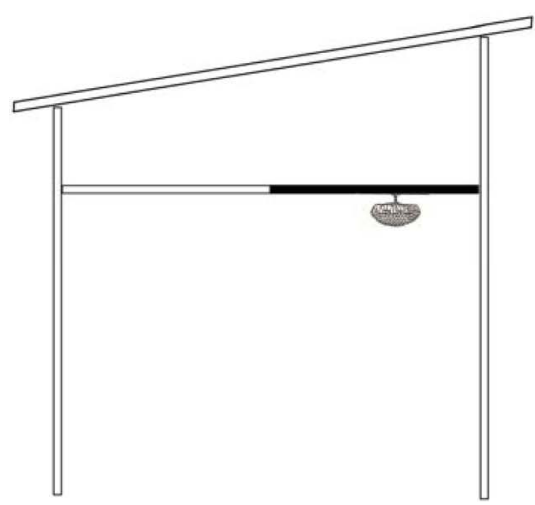

(c)

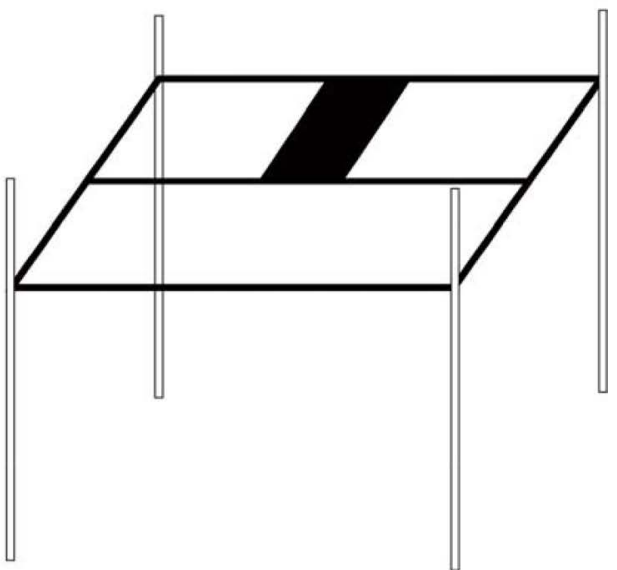

(b)

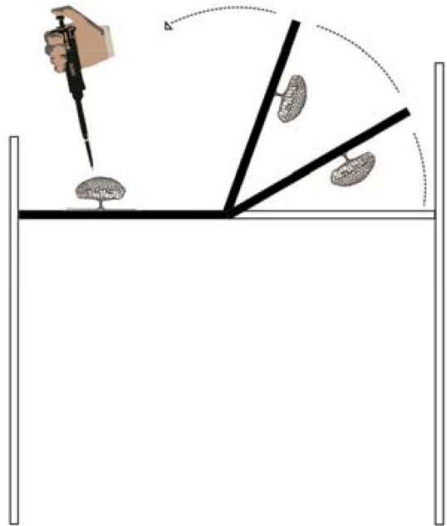

(d)

Figure 1. Schematic sketch of the artificial shelter used for colony maintenance. (a) Overview. (b) Internal view, indicating the exact position of the wooden board used for colony attachment. (c) Side view, showing the position of the colony attached to the wooden board. (d) Procedure for topical application of juvenile hormone by turning the wooden board 180 degrees.

was attached to clapboard inside the shelter, using a hinge (Figure 1(c)). The board could be rotated 180 degrees to enable topical application of JH to previously selected larvae (Figure 1(d)). To provide optimal conditions of temperature and humidity the colonies, each AS was installed next to shrub vegetation.

\subsection{Experimental Procedures}

Previous studies suggested that development reprogramming in IF eusocial wasps begins in the third larval instar [32] [33]. This stage in particular has been shown to be more sensitive to the factors controlling caste determination in highly eusocial wasps (subfamily Vespinae) [34]. Based on this premise, the treatments with JH were applied to batches of third, fourth and fifth instar larvae. The instar was determined based on the headcapsule width. In a previous study we determined the metric ranges of head-capsule width for each larval instar in M. consimilis. By mapping the nest on hexagon-printed paper [35], we followed the daily development of larvae in the comb in order to select the instars for each JH treatment.

The selected larvae were treated by topical application of a single dose of $1.0 \mu \mathrm{g} \mathrm{JH}$ III (Sigma-Aldrich, St. Louis, MO, USA) diluted in $1.0 \mu \mathrm{l}$ acetone, using an automatic micropipette with a volume of $2.0 \mu$ l. This dosage has been successfully used to assess $\mathrm{JH}$ effects on pre-imaginal caste determination in different species of eusocial insects [36]-[38]. For a larger number of JH-treated larvae, each treatment was conducted for four consecutive weeks, with three JH applications weekly. Untreated females that emerged in the experimental colonies were used as controls. 
Experimental manipulation of the transferred colonies was initiated only after the adults became visually habituated to the AS, i.e., when they began to add cells to the comb and to feed the larvae. To minimize possible effects of colony stage on the offspring, we transferred and manipulated only post-emergent colonies in workerphase (colony stage preceding the emergence of gynes). In an effort to minimize the stress caused by manipulation, all treatments were executed at night.

\subsection{Body Size and Ovarian Development of Newly Emerged Females}

Morphometric data were taken from a total of 118 newly emerged females, according to Gunnels [39]: head height, maximum distance among the inner margins of the eyes, minimum distance among the inner margins of the eyes, mesonotum length, mesonotum width, thorax length, mesopleura height, tibia length and forewing length. The degree of ovarian development of the newly emerged females was determined based on the presence or absence of pre-vitellogenic oocytes in the ovary. All measurements of body size and ovarian parameters were obtained with the aid of a Stemi 2000C stereomicroscope (Carl Zeiss Microscopy, Oberkochen, Germany), fitted with a micrometer eyepiece.

\subsection{Behavioral Phenotype and Ovarian Development of Mature Females}

Based on the premise that the behavioral ontogeny of females involves morphological and physiological maturation [40] [41], experimental females were observed after eight days of adulthood, which is the age when the behaviors assessed can potentially be performed by female M. consimilis [31]. A total of 37 experimental females were marked on the thorax with one or more colored dots of nontoxic ink soon after emergence, similarly to the procedure used by Nakata [42]. The behaviors assessed included time spent in the colony and the number of aggressive acts received per hour of nest presence, as described by Markiewicz and O'Donnell [43]. Continuous observations were made for two hours in the morning (09:00 - 11:00 h) and three hours in the evening (13:00 - 16:00 h), periods when colonies of this species are highly active [29]. Aggressive acts included individuals attacking, chasing, pecking, nibbling, holding in the mouth and sitting on each other, as described by Bruyndonckx et al. [44].

At the end of the observation period, the females were killed by freezing $\left(-20^{\circ} \mathrm{C}\right)$. The gaster of each experimental female was fixed by immersion in Dietrich's solution, and then stored in $70 \%$ ethanol. For analysis of ovarian development, the gasters were dissected in a petri dish containing physiological saline solution; for each female, the mean length of the six largest oocytes was used as the ovarian development index [27]. All measurements were taken with the aid of the Stemi 2000C stereomicroscope.

\subsection{Statistical Analyses}

All statistical analyses were carried out in an R Statistical Environment (R Development Core Team, 2013), with significance level of 0.05 . We measured nine morphometric variables of females emerging from JH-treated and control larvae, and evaluated them by a Principal Components Analysis (PCA) with the help of the labdsv package [45]. The first PCA component was used as a body size index [39]. Data for body size were normally distributed (Shapiro-Wilk test, $P>0.05$ ) and showed variance homogeneity (Bartlett's test, $P>0.05$ ), so the differences between the categories of females were evaluated by parametric tests, including Analysis of Variance (ANOVA) and Dunnett's test for multiple comparisons with the use of the asbio package [46]. The data for ovarian development of newly emerged females were analyzed using Chi-square $\left(\chi^{2}\right)$.

Behavioral and ovarian-development data for mature females were not normally distributed (Shapiro-Wilk test, $P<0.05$ ), and therefore differences among groups were assessed by nonparametric tests, including the Kruskal-Wallis and Mann-Whitney $U$ test for multiple comparisons, with the help of the exactRankTests package [47], followed by Bonferroni correction.

\section{Results}

\subsection{Effect of Larval Topical Application of JH on Body Size and Ovarian Development of Newly Emerged Females}

The PCA with the nine morphometric variables recovered most of the existing variance among the four categories of experimental females. The first PCA axis was positively associated with all morphometric variables, and 
explained $78.3 \%$ of the total variation. The second axis explained $10.3 \%$ of the total variation. Considering the first principal component as the explanatory variable, significant differences in body size were found between the treatment and control females (ANOVA, $F_{3.114}=3.15, P=0.02$, Figure 2). Comparisons of pairs of groups showed that only females emerging from third-instar JH-treated larvae had a significantly larger body size than females emerging from control larvae (Dunnett's test, $P<0.01$, Figure 2). Larval topical application of JH did not affect the degree of ovarian development in newly emerged females (Chi-square, $\chi^{2}=1.48, P=0.68$, Table $1)$.

\subsection{Effect of Larval Topical Application of JH on Behavioral Phenotype and Ovarian Development of Mature Females}

The time spent in the nest differed significantly between the treatment and control females (Kruskal-Wallis, $H=$ 12.02, $d f=3, P<0.01$, Figure 3). Comparison of the groups showed that females emerging from third-instar JH-treated larvae spent significantly more time in the nest compared to females emerging from control larvae (Mann-Whitney $U$ test, $P<0.01$, after Bonferroni correction; Figure 3).

The number of aggressive acts received per hour spent in the nest differed significantly between the treatment and control females (Kruskal-Wallis, $H=22.03, d f=3, P<0.001$, Figure 4). Pairwise comparison of groups showed that females emerging from third- and fourth-instar JH-treated larvae (Mann-Whitney $U$ test, $P<0.001$ and $P=0.03$, respectively, after Bonferroni correction; Figure 4) received significantly less physical aggression from nestmates compared to females emerging from control larvae. The degree of ovarian development did not differ significantly between the treatment and control females (Kruskal-Wallis, $H=6.77, d f=3, P=0.08$ ).

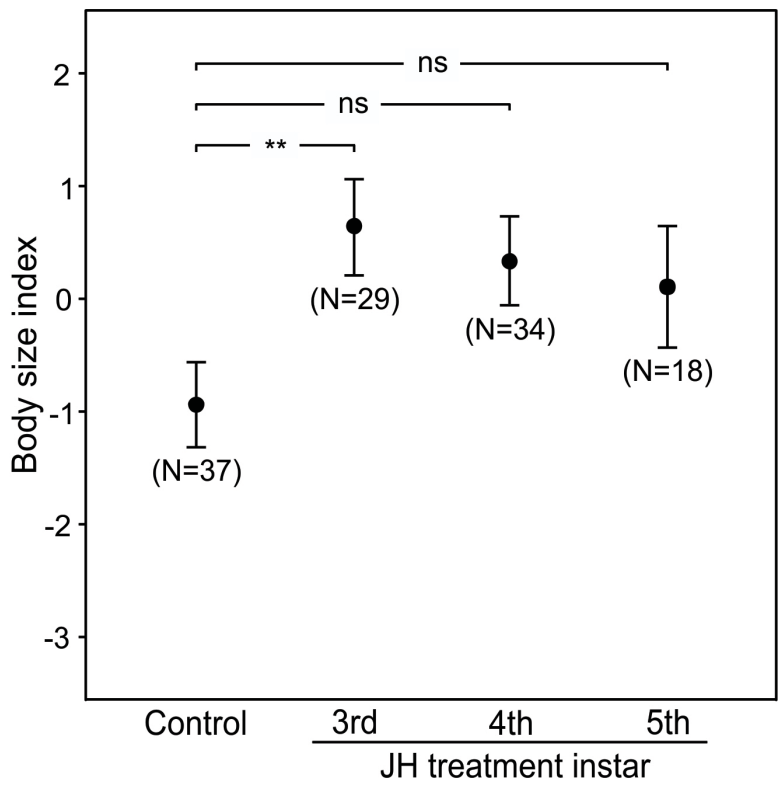

Figure 2. Variation in body size index (mean $\pm \mathrm{SD}$ ) for females of Mischocyttarus consimilis, whose larvae were treated with juvenile hormone in different larval instars, and untreated controls. $^{* *}(P<0.01)$; ns indicates no significant difference $(P>0.05)$.

Table 1. Number of occurrence of two types of ovaries in 118 females of Mischocyttarus consimilis, whose larvae were treated with juvenile hormone in different larval instars, and untreated controls.

\begin{tabular}{|c|c|c|c|c|}
\hline \multirow{2}{*}{ Ovarian type } & \multirow{2}{*}{ Control } & \multicolumn{3}{|c|}{$\mathrm{JH}$ treatment instar } \\
\hline & & $3 \mathrm{rd}$ & 4 th & 5 th \\
\hline Ovary filamentous & 23 & 14 & 19 & 9 \\
\hline Ovary with previtellogenic oocytes & 14 & 15 & 15 & 9 \\
\hline
\end{tabular}




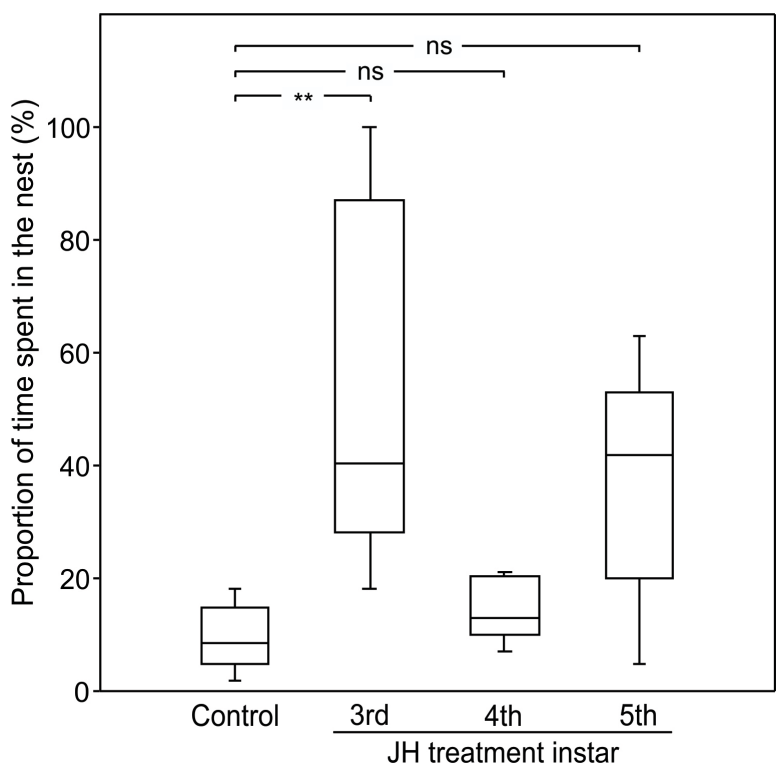

Figure 3. Proportion of time (\%) spent in the nest by females of Mischocyttarus consimilis, whose larvae were treated with juvenile hormone in different larval instars, and untreated controls. Box-plot represents the median, $25 \%-75 \%$ percentiles and minimum/maximum range. ${ }^{* *}(P<0.01)$; ns $(P>0.05)$, after Bonferroni correction.

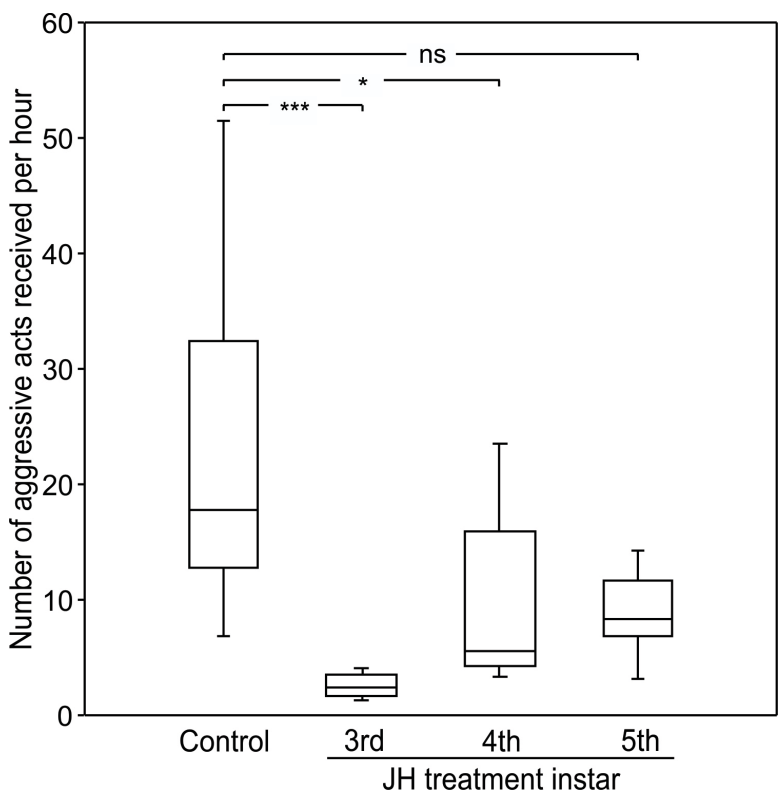

Figure 4. Number of aggressive acts per hour, received by females of Mischocyttarus consimilis, whose larvae were treated with juvenile hormone in different larval instars, and untreated controls. Box-plot represents the median, 25\% $75 \%$ percentiles and minimum/maximum range. ${ }^{* * *}(P<$ $0.001) ;{ }^{*}(P<0.05)$; ns $(P>0.05)$, after Bonferroni correction.

\section{Discussion}

This study demonstrated for the first time that JH topical application in a specific period of larval development 
affects the female's phenotype in IF eusocial wasps. Females emerging from JH-treated larvae in the third instar had a significantly larger body size than females emerging from control larvae. This instar-dependent effect of $\mathrm{JH}$ on the offspring phenotype has been described for other species of eusocial insects [38] [48]. For example, in the ant Harpegnathos saltator, an increase of JH titer in larvae of the third and fourth (last) instars is sufficient to induce the queen to develop [38]. In honey bee (Apis mellifera), JH topical application effectively inhibited programmed cell death in ovarioles of third-instar larvae developing into workers [49].

In different animal societies, body size is an attribute of high social value and has been a major force promoting the reproductive division of labor among castes in eusocial insects [50]. Although smaller females of IF eusocial wasps retain the ability to reproduce, larger females are more likely to perform direct reproduction, due to their greater potential for both dominance and ovarian development [51] [52]. For example, Cervo et al. [53] showed for $P$. dominula that females exercising their reproductive function were larger than subordinate females in 35 of 48 associative foundations. It has been suggested that morphological differentiation among potential females could reduce the cost of reproductive conflicts, especially for species of eusocial insects that conduct aggressive disputes for direct reproduction [54] [55].

Our results are consistent with the supposition that the offspring's phenotype in colonies of eusocial insects can be affected by social variables, including manipulation of the phenotype by adults [56]. Immature eusocial insects are totally dependent on the adults for care, so the allocation of caste may be subject to social interests [57] [58]. Thus, control over the offspring phenotype is critical to social stability, since the caste allocation must be adjusted according to demand throughout the colony cycle [33] [57]. Recent studies have reinforced this hypothesis by demonstrating that adults in colonies of eusocial wasps can control the development of immatures, to produce workers and gynes at the beginning and end of the colony cycle, respectively [32] [33]. Suryanarayanan et al. [33] showed that larvae of Polistes fuscatus in pre-emergence colonies experience high levels of antennation (drumming on the walls of cells occupied by larvae) compared to the larvae present in post-emergence colonies. Antennation produces vibration, acting as a mechanism to promote stress, and larvae subjected to high levels of vibration during development emerge with the typical worker phenotype, while those experiencing low levels emerge with the typical gyne phenotype [32] [59]. It remains to be determined whether the mechanical interference affects the phenotype via changes in the JH titers.

Variations in the $\mathrm{JH}$ titers during pre-imaginal caste determination in eusocial wasps can be analyzed nutritionally. The mechanisms controlling the biosynthesis of JH in the corpora alata of immature holometabolous insects are strongly affected by nutritional variables [60]. For example, in honey bee, elevated JH titers leading to development reprogramming occur only in larvae with a highly nutritious diet, i.e., based on royal jelly [48] [61]. Similarly, larval feeding can be decisive in pre-imaginal caste determination in the eusocial bee Bombus terrestris, when a higher food intake increases biosynthesis of JH in larvae developing into queens [62] [63]. In eusocial wasps, an association between larval diet and JH biosynthesis has not yet been reported, although such an association is likely in independent-founding species [15] [59].

Females emerging from larvae treated with JH in the third instar spent more time in the nest compared to control females. We interpret this behavior as a strategy adopted by females who are seeking to reproduce [6] [40] [64]. Tasks that involve a high energy cost, such as foraging for food and nest-building material, may be avoided by females that intend to invest in reproduction themselves [54] [64]. Thus, individuals with a higher probability of reproducing are predicted to invest less in helping their maternal colony [28].

Mature females emerging from larvae treated with $\mathrm{JH}$ in the third instar received less physical aggression from nestmates, compared to control females. Molina and O'Donnell [40] demonstrated that workers of the wasp Mischocyttarus mastigophorus receive their first aggressive acts on about the fifth day after emerging. The age at which workers are subject to the highest rates of aggression is linked with the onset of foraging activity. In $M$. consimilis, eight-day-old workers already forage at high rates, and this activity increases with rising rates of receiving aggression [31] [personal observation]. In contrast, eight-day-old gynes spend most of their time in the colony and are subject to low aggression rates [personal observation], suggesting that females emerging from larvae treated with JH in the third instar showed a gyne-like behavioral phenotype. Our results reinforce the hypothesis that expression of gyne-like behavior only occurs in adult females that experience elevated JH titers in a specific pre-imaginal period.

However, topical application of $\mathrm{JH}$ to the larvae did not lead to greater ovarian development in mature females, although there was a tendency to this. These data can be partly explained by the fact that females emerging in the early colonies, which feature a highly fertile queen, such as those in the experimental colonies, may be 
intimidated from investing in ovarian development. In colonies of eusocial wasps, subordinate females can assess the fertility of the queen by monitoring chemical cues secreted by the Van der Vecht gland or by directly estimating the density of immatures in the comb [65] [66]. In other studies with IF eusocial wasps, mature females showed a significant increase in ovarian development in an environment without queens [51] [52].

\section{Conclusion}

The results presented in this study, especially those showing morphological and behavioral differences between females emerging from third-instar $\mathrm{JH}$-treated larvae and females emerging from control larvae, suggest that JH plays an important role in pre-imaginal caste determination in IF eusocial wasps, and that its effect is instar-dependent. This new information on pre-imaginal variables influencing individual phenotypes raises important questions about the mechanisms that control phenotypic plasticity in insects, and may help to answer questions involving the relationships among the developmental history, morphology and behavioral expression in adults of eusocial insects. Further studies are needed to clarify which factors affect variations in the JH titers during preimaginal caste determination in IF eusocial wasps, such as nutrition, levels of exposure to stress, or other still unknown factors.

\section{Acknowledgements}

The authors acknowledge the Fundação de Apoio ao Desenvolvimento do Ensino, Ciência e Tecnologia do Estado de Mato Grosso do Sul (FUNDECT) for financial support (Proc. No. 23/200.767/2012), and the Coordenação de Aperfeiçoamento de Pessoal de Nível Superior (CAPES) for the scholarship granted to the first author. WFAJ thanks the Conselho Nacional de Desenvolvimento Científico e Tecnológico (CNPq) for the research productivity scholarship. We also thank Janet W. Reid for the revision of the English text.

\section{References}

[1] Robinson, G.E. (1992) Regulation of Division of Labor in Insect Societies. Annual Reviews of Entomology, 37, 637665. http://dx.doi.org/10.1146/annurev.en.37.010192.003225

[2] Strassmann, J.E. and Meyer, D.C. (1983) Gerontocracy in the Social Wasp, Polistesexclamans. Animal Behaviour, 31, 431-438. http://dx.doi.org/10.1016/S0003-3472(83)80063-3

[3] Bang, A. and Gadagkar, R. (2012) Reproductive Queue without Overt Conflict in the Primitively Eusocial Wasp Ropalidia marginata. Proceedings of the National Academy of Sciences of the United States of America, 109, 14494-14499. http://dx.doi.org/10.1073/pnas.1212698109

[4] Bridge, C. and Field, J. (2007) Queuing for Dominance: Gerontocracy and Queue-Jumping in the Hover Wasp Liostenogaster flavolineata. Behavioral Ecology and Sociobiology, 61, 1253-1259. http://dx.doi.org/10.1007/s00265-007-0355-9

[5] Hughes, C.R. and Strassmann, J. E. (1988) Age Is More Important than Size in Determining Dominance among Workers in the Primitively Eusocial Wasp, Polistes instabilis. Behaviour, 107, 1-14. http://dx.doi.org/10.1163/156853988X00151

[6] Molina, Y. and O'Donnell, S. (2009) Worker Reproductive Competition Affects Division of Labor in a Primitively Social Paperwasp (Polistes instabilis). Insectes Sociaux, 56, 14-20. http://dx.doi.org/10.1007/s00040-008-1027-0

[7] O'Donnell, S. (1998) Reproductive Caste Determination in Eusocial Wasps (Hymenoptera: Vespidae). Annual Reviews of Entomology, 43, 323-446. http://dx.doi.org/10.1146/annurev.ento.43.1.323

[8] Mead, F. and Gabouriaut, D. (1993) Post-Eclosion Sensitivity to Social Context in Polistes dominulus Christ Females (Hymenoptera, Vespidae). Insectes Sociaux, 40, 11-20. http://dx.doi.org/10.1007/BF01338829

[9] West-Eberhard, M.J. (1969) The Social Biology of Polistine Wasps. Miscellaneous Publications Museum of Zoology, 140, 1-101.

[10] Haggard, C.M. and Gamboa, G.J. (1980) Seasonal Variation in Body Size and Reproductive Condition of a Paper Wasp, Polistes metricus (Hymenoptera: Vespidae). The Canadian Entomologist, 112, 239-248. http://dx.doi.org/10.4039/Ent112239-3

[11] Keeping, M.G. (2002) Reproductive and Worker Castes in the Primitively Eusocial Wasp Belonogaster petiolata (DeGeer) (Hymenoptera: Vespidae): Evidence for Pre-Imaginal Differentiation. Journal of Insect Physiology, 48, 867-879. http://dx.doi.org/10.1016/S0022-1910(02)00156-7

[12] Dapporto, L., Petrocelli, I. and Turillazzi, S. (2011) Incipient Morphological Castes in Polistes gallicus (Vespidae, 
Hymenoptera). Zoomorphology, 130, 197-201. http://dx.doi.org/10.1007/s00435-011-0130-3

[13] Petrocelli, I. and Turillazzi, S. (2013) The Morphology of Van der Vecth's Organ as a Tool to Measure Caste Dimorphism in Polistes Paper Wasps: A Comparative Approach. Journal of Zoological Systematics and Evolutionary Research, 51, 274-278. http://dx.doi.org/10.1111/jzs.12028

[14] Sumner, S., Pereboom, J.J.M. and Jordan, W.C. (2006) Differential Gene Expression and Phenotypic Plasticity in Behavioural Castes of the Primitively Eusocial Wasp, Polistes canadensis. Proceedings of the Royal Society B, 273, 1926. http://dx.doi.org/10.1098/rspb.2005.3291

[15] Hunt, J.H., Wolschin, F., Henshaw, M.T., Newman, T.C., Toth, A.L. and Amdam, G.V. (2010) Differential Gene Expression and Protein Abundance Evince Ontogenetic Bias toward Castes in a Primitively Eusocial Wasp. PLoS ONE, 5, e10674. http://dx.doi.org/10.1371/journal.pone.0010674

[16] Azevedo, S.V., Caranton, O.A.M., Oliveira, T.L. and Hartfelder, K. (2011) Differential Expression of Hypoxia Pathway Genes in Honey Bee (Apis mellifera L.) Caste Development. Journal of Insect Physiology, 57, 38-45. http://dx.doi.org/10.1016/j.jinsphys.2010.09.004

[17] Evans, J.D. and Wheeler, D.E. (2001) Gene Expression and the Evolution of Insect Polyphenisms. BioEssays, 23, 6268. http://dx.doi.org/10.1002/1521-1878(200101)23:1<62::AID-BIES1008>3.3.CO;2-Z

[18] Schwander, T., Lo, N., Beekman, M., Oldroyd, B.P. and Keller, L. (2010) Nature versus Nurture in Social Insect Caste Differentiation. Trends in Ecology and Evolution, 25, 275-282. http://dx.doi.org/10.1016/j.tree.2009.12.001

[19] Wheeler, D.E., Buck, N. and Evans, J.D. (2006) Expression of Insulin Pathway Genes during the Period of Caste Determination in the Honey Bee, Apis mellifera. Insect Molecular Biology, 15, 597-602. http://dx.doi.org/10.1111/j.1365-2583.2006.00681.x

[20] Barchuk, A.R., Cristino, A.S., Kucharski, R., Costa, L.F., Simões, Z.L.P. and Maleszka, R. (2007) Molecular Determinants of Caste Differentiation in the Highly Eusocial Honeybee Apis mellifera. BMC Developmental Biology, 7, 70. http://dx.doi.org/10.1186/1471-213X-7-70

[21] Tibbetts, E.A. (2006) Badges of Status in Worker and Gyne Polistes dominulus Wasps. Annales Zoologici Fennici, 43, $575-582$.

[22] Hunt, J.H., Kensinger, B.J., Kossuth, J.A., Henshaw, M.T., Norberg, K., Wolschin, F. and Amdam, G.V. (2007) A Diapause Pathway Underlies the Gyne Phenotype in Polistes Wasps, Revealing an Evolutionary Route to Caste-Containing Insect Societies. Proceedings of the National Academy of Sciences of the United States of America, 104, 1402014025. http://dx.doi.org/10.1073/pnas.0705660104

[23] Dapporto, L., Lambardi, D. and Turillazzi, S. (2008) Not Only Cuticular Lipids: First Evidence of Differences between Foundresses and Their Daughters in Polar Substances in the Paper Wasp Polistes dominulus. Journal of Insect Physiology, 54, 89-95. http://dx.doi.org/10.1016/j.jinsphys.2007.08.005

[24] Jeanne, R.L. (1972) Social Biology of the Neotropical Wasp Mischocyttarus drewseni. Bulletin of the Museum of Comparative Zoology, 144, 63-150.

[25] Torres, V.O., Montagna, T.S., Fernandes, W.D. and Antonialli-Junior, W.F. (2011) Colony Cycle of the Social Wasp Mischocyttarus consimilis Zikán (Hymenoptera: Vespidae). Revista Brasileira de Entomologia, 55, 247-252. http://dx.doi.org/10.1590/S0085-56262011000200016

[26] Dani, F.R. (1994) Caste Size Differences in Polistes gallicus (L.) (Hymenoptera: Vespidae). Ethology Ecology \& Evolution, 6, 67-73. http://dx.doi.org/10.1080/03949370.1994.10721976

[27] Giray, T., Giovanetti, M. and West-Eberhard, M.J. (2005) Juvenile Hormone, Reproduction, and Worker Behavior in the Neotropical Social Wasp Polistes canadensis. Proceedings of the National Academy of Sciences of the United States of America, 102, 3330-3335. http://dx.doi.org/10.1073/pnas.0409560102

[28] Keeping, M.G. (1997) Social Behavior and Brood Decline in Reproductive-Phase Colonies of Belonogaster petiolata (Degeer) (Hymenoptera: Vespidae). Journal of Insect Behavior, 10, 265-278. http://dx.doi.org/10.1007/BF02765559

[29] Montagna, T.S., Torres, V.O., Dutra, C.C., Súarez, Y.R., Antonialli-Junior, W.F. and Alves-Junior, V.V. (2009) Study of the Foraging Activity of Mischocyttarus consimilis (Hymenoptera: Vespidae). Sociobiology, 53, 131-140.

[30] Montagna, T.S., Torres, V.O., Fernandes, W.D. and Antonialli-Junior, W.F. (2010) Nest Architecture, Colony Productivity, and Duration of Immature Stages in a Social Wasp, Mischocyttarus consimilis. Journal of Insect Science, 10, 1 12. http://dx.doi.org/10.1673/031.010.19101

[31] Torres, V.O., Montagna, T.S., Raizer, J. and Antonialli-Junior, W.F. (2012) Division of Labor in Colonies of the Eusocial Wasp, Mischocyttarus consimilis. Journal of Insect Science, 12, 1-15. http://dx.doi.org/10.1673/031.012.2101

[32] Suryanarayanan, S. and Jeanne, R.L. (2008) Antennal Drumming, Trophallaxis, and Colony Development in the Social Wasp Polistes fuscatus (Hymenoptera: Vespidae). Ethology, 114, 1201-1209. http://dx.doi.org/10.1111/j.1439-0310.2008.01561.x 
[33] Suryanarayanan, S., Hantschel, A.E., Torres, C.G. and Jeanne, R.L. (2011) Changes in the Temporal Pattern of Antennal Drumming Behavior Across the Polistes fuscatus Colony Cycle (Hymenoptera: Vespidae). Insectes Sociaux, 58, 97-106. http://dx.doi.org/10.1007/s00040-010-0122-1

[34] Ishay, J. (1975) Caste Determination by Social Wasps: Cell Size and Building Behaviour. Animal Behaviour, 23, 429431. http://dx.doi.org/10.1016/0003-3472(75)90090-1

[35] Hunt, J.H., Mutti, N.S., Havukainen, H., Henshaw, M.T. and Amdam, G.V. (2011) Development of an RNA Interference Tool, Characterization of Its Target, and an Ecological Test of Caste Differentiation in the Eusocial Wasp Polistes. PLoS ONE, 6, e26641. http://dx.doi.org/10.1371/journal.pone.0026641

[36] Wheeler, D.E. and Nijhout, H.F. (1983) Soldier Determination in Pheidole bicarinata: Effect of Methoprene on Caste and Size within Castes. Journal of Insect Physiology, 29, 847-854. http://dx.doi.org/10.1016/0022-1910(83)90151-8

[37] Antonialli-Junior, W.F. and Cruz-Landim, C. (2006) Effect of Topical Application of Juvenile Hormone on the Occurrence of Cell Death in the Larvae of Honeybee (Apis mellifera). Brazilian Journal of Morphological Sciences, 23, 377383.

[38] Penick, C.A., Prager, S.S. and Liebig, J. (2012) Juvenile Hormone Induces Queen Development in Late-Stage Larvae of the Ant Harpegnathos saltator. Journal of Insect Physiology, 58, 1643-1649. http://dx.doi.org/10.1016/j.jinsphys.2012.10.004

[39] Gunnels, C.W. (2007) Seasonally Variable Eusocially Selected Traits in the Paper Wasp, Mischocyttarus mexicanus. Ethology, 113, 648-660. http://dx.doi.org/10.1111/j.1439-0310.2007.01358.x

[40] Molina, Y. and O’Donnell, S. (2008) A Developmental Test of the Dominance-Nutrition Hypothesis: Linking Adult Feeding, Aggression, and Reproductive Potential in the Paperwasp Mischocyttarus mastigophorus. Ethology Ecology \& Evolution, 20, 125-139. http://dx.doi.org/10.1080/08927014.2008.9522533

[41] Molina, Y. and O’Donnell, S. (2009) Males Exhibit Novel Relationships of Dominance with Nest Departure in the Social Paper Wasp Mischocyttarus mastigophorus (Hymenoptera: Vespidae). Ethology, 115, 738-746. http://dx.doi.org/10.1111/j.1439-0310.2009.01659.x

[42] Nakata, K. (1996) The Difference in Behavioral Flexibility among Task Behaviors in a Ponerinae Ant, Diacamma sp. Sociobiology, 27, 119-127.

[43] Markiewicz, D.A. and O’Donnell, S. (2001) Social Dominance, Task Performance and Nutrition: Implications for Reproduction in Eusocial Wasps. Journal of Comparative Physiology A, 187, 327-333. http://dx.doi.org/10.1007/s003590100204

[44] Bruyndonckx, N., Kardile, S.P. and Gadagkar, R. (2006) Dominance Behaviour and Regulation of Foraging in the Primitively Eusocial Wasp Ropalidia marginata (Lep.) (Hymenoptera: Vespidae). Behavioural Processes, 72, $100-103$. http://dx.doi.org/10.1016/j.beproc.2005.11.013

[45] Roberts, D.W. (2012) Ordination and Multivariate Analysis for Ecology. R Package Version 1.0-5. http://CRAN.R-project.org/package=labdsv

[46] Aho, K. (2013) A Collection of Statistical Tools for Biologists. R Package Version 1.0. http://CRAN.R-project.org/package=asbio

[47] Hothorn, T. and Hornik, K. (2013) Exact Distributions for Rank and Permutation Tests. R Package Version 0.8-27. http://CRAN.R-project.org/package=exactRankTests

[48] Rachinsky, A. and Hartfelder, K. (1990) Corpora Allata Activity, a Prime Regulating Element for Caste-Specific Juvenile Hormone Titre in Honey Bee Larvae (Apis mellifera carnica). Journal of Insect Physiology, 36, 189-194. http://dx.doi.org/10.1016/0022-1910(90)90121-U

[49] Antonialli-Junior, W.F. and Cruz-Landim, C. (2009) Efeitos da aplicação tópica de hormônio juvenil sobre o desenvolvimento dos ovários de larvas de operárias de Apis mellifera Linnaeus (Hymenoptera: Apidae). Revista Brasileira de Entomologia, 53, 115-120. http://dx.doi.org/10.1590/S0085-56262009000100025

[50] O'Donnell, S. (1995) Division of Labor in Post-Emergence Colonies of the Primitively Eusocial Wasp Polistes instabilis de Saussure (Hymenoptera: Vespidae). Insectes Sociaux, 42, 17-29. http://dx.doi.org/10.1007/BF01245696

[51] Tibbetts, E.A. and Sheehan, M.J. (2012) The Effect of Juvenile Hormone on Polistes Wasp Fertility Varies with Cooperative Behavior. Hormones and Behavior, 61, 559-564. http://dx.doi.org/10.1016/j.yhbeh.2012.02.002

[52] Shukla, S., Shilpa, M.C. and Gadagkar, R. (2013) Virgin Wasps Develop Ovaries on Par with Mated Females, but Lay Fewer Eggs. Insectes Sociaux, 60, 345-350. http://dx.doi.org/10.1007/s00040-013-0299-1

[53] Cervo, R., Dapporto, L., Beani, L., Strassmann, J.E. and Turillazzi, S. (2008) On Status Badges and Quality Signals in the Paper Wasp Polistes dominulus: Body Size, Facial Colour Patterns and Hierarchical Rank. Proceedings of the Royal Society B, 275, 1189-1196. http://dx.doi.org/10.1098/rspb.2007.1779

[54] Reeve, H.K. (1991) Polistes. In: Ross, K.G. and Matthews, R.W., Eds., The Social Biology of Wasps, Cornell Univer- 
sity Press, Ithaca, 99-148.

[55] Bourke, A.F.G. (1999) Colony Size, Social Complexity and Reproductive Conflict in Social Insects. Journal of Evolutionary Biology, 12, 245-257. http://dx.doi.org/10.1046/j.1420-9101.1999.00028.x

[56] Bourke, A.F.G. and Ratnieks, F.L.W. (1999) Kin Conflict over Caste Determination in Social Hymenoptera. Behavioral Ecology and Sociobiology, 46, 287-297. http://dx.doi.org/10.1007/s002650050622

[57] Penick, C.A. and Liebig, J. (2012) Regulation of Queen Development through Worker Aggression in a Predatory Ant. Behavioral Ecology, 23, 992-998. http://dx.doi.org/10.1093/beheco/ars062

[58] Kwapich, C.L. and Tschinkel, W.R. (2013) Demography, Demand, Death, and the Seasonal Allocation of Labor in the Florida Harvester Ant (Pogonomyrmex badius). Behavioral Ecology and Sociobiology, 67, 2011-2027. http://dx.doi.org/10.1007/s00265-013-1611-9

[59] Suryanarayanan, S., Hermanson, J.C. and Jeanne, R.L. (2011) A Mechanical Signal Biases Caste Development in a Social Wasp. Current Biology, 21, 231-235. http://dx.doi.org/10.1016/j.cub.2011.01.003

[60] Mirth, C.K. and Riddiford, L.M. (2007) Size Assessment and Growth Control: How Adult Size Is Determined in Insects. BioEssays, 29, 344-355. http://dx.doi.org/10.1002/bies.20552

[61] Rachinsky, A. and Hartfelder, K. (1991) Differential Production of Juvenile Hormone and Its Desoxy Precursor by Corpora Allata of Honeybees during a Critical Period of Caste Development. Naturwissenschaften, 78, 270-272. http://dx.doi.org/10.1007/BF01134355

[62] Ribeiro, M.F., Velthuis, H.H.W., Duchateau, M.J. and van der Tweel, I. (1999) Feeding Frequency and Caste Differentiation in Bombus terrestris Larvae. Insectes Sociaux, 46, 306-314. http://dx.doi.org/10.1007/s000400050150

[63] Cnaani, J., Robinson, G.E. and Hefetz, A. (2000) The Critical Period for Caste Determination in Bombus terrestris and Its Juvenile Hormone Correlates. Journal of Comparative Physiology A, 186, 1089-1094. http://dx.doi.org/10.1007/s003590000163

[64] Tibbetts, E.A. (2007) Dispersal Decisions and Predispersal Behavior in Polistes Paper Wasp "Workers". Behavioral Ecology and Sociobiology, 61, 1877-1883. http://dx.doi.org/10.1007/s00265-007-0427-x

[65] Dapporto, L., Santini, A., Dani, F.R. and Turillazzi, S. (2007) Workers of a Polistes Paper Wasp Detect the Presence of Their Queen by Chemical Cues. Chemical Senses, 32, 795-802. http://dx.doi.org/10.1093/chemse/bjm047

[66] Liebig, J., Monnin, R. and Turillazzi, S. (2005) Direct Assessment of Queen Quality and Lack of Worker Suppression in a Paper Wasp. Proceedings of the Royal Society B, 272, 1339-1344. http://dx.doi.org/10.1098/rspb.2005.3073 